\title{
Armağanın Değişen Sosyo-Kültürel Anlamları: Tüketim Toplumu Bağlamında Bir Hediyeleşme Örneği Olarak Çiçek Gönderme*
}

\author{
Socio-Cultural Definitions of Gift: Sending Flowers as an Example of \\ Giving a Gift within the Context of the Consumer Society
}

Gönül DEMEZ**

Özet: Toplumsal dayanışmanın kaynağının armağan ilişkisi olduğunu savunan düşünceye göre, toplumsal ilişkilerin sürekliliği armağanın karşılıklılık ilkesiyle sağlanır. Armağan vermenin ve armağanı geri vermenin yarattığı zorunluluk nedeniyle insanlar arasında kurulan etkileşim süreklilik kazanır ve bu etkileşim aracılığıyla insanlar arasında oluşan bağın kopması engellenir. Bu ilişki ağıyla nesnelerin, duyguların, kültürün aktarımı sağlanır. Bu çalışmada yalın toplumlarda Potlaç olarak adlandırılan ve verme, harcama, yok etme, tüketme aracılığıyla bir güç gösterisi ve iktidar aracına dönüşen toplumsal şölenlerden günümüzün incelikli sunumuyla dönüşen armağan verme ilişkileri, toplumsal değişme bağlamında çözümlenecektir. $\mathrm{Bu}$ anlamda yalın toplumlardan günümüz Tüketim Toplumu'na, toplumsal değişme ve armağanın dönüşen ifadesi çiçek gönderme ritüeli üzerinden tartışlacaktır.

Anahtar sözcükler: Armağan, potlaç, değişim, toplumsal dayanışma, toplumsal etkileşim, çiçek

Abstract: According to the thought, asserting that the gift was a source of social solidarity, the continuity of social relations is provided by the principle of reciprocity. Due to the requirement in giving and getting a gift, the interaction between people becomes continuous and it prevents the breakdown in connections between people. This network of relations enables the transmission of the objects, emotions and the culture. In this study, what is called in primitive societies Potlatch, means spending, destroying, consuming via the show of force and power. Today's sophisticated gift giving ceremonies will be analyzed in the context of social change. In this sense, transforming a gift will also be analyzed through the ritual of sending flowers in the context of social change from the period of primitive societies into today's Consumer Society.

Keywords: Gift, potlatch, exchange, social solidarity, social interaction, flower

“Armağanlar köleler yaratır, tıpkı kırbaçların köpekler yaratması gibi”

(Eskimo atasözü, aktaran; Harris, 1995, 110)

Toplumsal bilimlerin temel sorularından olan, toplumsal düzenin ve toplumsal dayanışmanın kaynağ 1 ve bunu sağlayan birleştirici güçlerin hangi süreçler olduğu ve toplumsal düzenin nasıl devam ettiği gibi temel alanlar çözümlenirken, karş1lıklılık ve bağımlılık ilişkileri dikkatleri çekmiştir. Kültürün dayandığı ilkenin toplumsal etkileşim yani bir tür alışveriş olması, toplumsal ilişkilerin özünü araştıran sosyal bilimcilerin dikkatini toplumdaki mübadele ilişkileri ve biçimlerine yöneltmiştir. İnsanlar arası etkileşimde genellikle birbiriyle çelişen iki tip belirleyici

\footnotetext{
* Bu çalışmada armağan ve hediye kavramları benzer anlamda kullanılmakla birlikte, armağan kavramı Antropolojik olarak harcama ekonomisi ve zorunlu olarak karşılıklılı̆ga dayanan toplumsal yapıyı ifade etmektedir. Hediye ise, daha çok etkileşim bağlamında bireyler arası duruma işaret etmektedir.

** Yrd. Doç. Dr., Akdeniz Üniversitesi, Edebiyat Fakültesi, Sosyoloji Bölümü, Antalya, gonuldemez@gmail.com
} 
ilkenin etken olduğunu söyleyen Bauman'a $(1998,102)$ göre eşdeğerler mübadelesi ve armağan olarak tanımlanan bu ilkeler, toplumsal ilişkinin belirleyicileridirler. Bu düşünce modern insan yaşamının bu iki ilke aracılığıyla kişisel olan ve kişisel olmayan bir bağlam arasında gerçekleştiğini ifade eder. Özkaya $(2011,81)$ sonu ölümle bitebilecek açl1k grevlerini Mauss'un çalışmalarına dayandırarak alturistik bir armağan olarak değerlendirdiği çalışmasında armağanı; Godbout'a atıfla "bireyler arası sosyal bağları inşa etmek, yeniden üretmek amacıyla verilen ve karşıllklılık garantisi olmayan her türlü mal ve hizmet olarak" tanımlamaktadır. Mauss'un armağan kavramı toplumların oluşumunu ifade eden önemli kavramlardandır. Almak, vermek, mübadele, kurban, yas gibi toplumsal ritüeller, tüm sosyal kurumların ve toplumsal yapının oluşmasını sağlayan olguları tanımlayan ana kavramlardır. Armağandan hareketle toplumun oluşumunun sözleşmelere dayandığını savunan fikir akımlarına vurgu yapan düşünce sistemleri dikkate alındığında (Rousseau, Hobbes, Locke gibi) toplumsal örgütlenmenin işleyişinin armağandan toplumsal sözleşmelere doğru ilerlediği anlaşılmaktadır (Akay, 1999, 131). Yine Akay'a göre; Mauss tarafından yaban, yani ilkel toplumların antropolojik olarak toplumsallıklarını belirleyen bu kavramların Batı toplumları için de kullanılabilir olma ihtimalini gözden kaçırmamak gereklidir.

Toplumsal etkileşim alanında nesneler kendi kendilerine dolaşıma girmezler. Nesnelerin toplumsal hayattaki dolaşımını belirleyen toplumsal bir iradeden söz edilebilir. Bu yolla söz konusu değişim nesneleri, bu irade aracılığıyla anlam kazanmaktadır. Böylece, mübadele biçimlerinin bir toplumda hem iradeyi hem de özgürlüğü oluşturduğu söylenebilir. Armağan ve karş1 armağan bir toplumsal döngüye dönüşmekte ve bu döngü toplumsal bağın kurulmasını sağlamaktadır (Akay, 1999, 160). Dolayısıyla kimliklerin, bireylerin, kendilerini ifade ediş biçimleri bu bağlanma aracıllğıyla oluşur. Bir değişim modelinin olduğu her yerde ya da toplumsal bir değişim döngüsünden bahsedildiğinde, bu ilişki gerek armağan gerekse alışveriş temelli olsun; tüm ilişkilerin farklı bireyler arasındaki etkileşime dayandığı kabul edilirse (Game, \& Metcalfe, 2010); armağan ilişkisi kişisel bir eylem gibi gözükse bile aynı zamanda belirli toplumsal kurallar içerisinde gerçekleştiği için de toplumsal bir olgudur. Çünkü bireyin eylemini kendi iradesiyle gerçekleştirmesi nedeniyle kişiseldir; ancak armağan ilişkisi aynı zamanda geleneğe bağlı olarak gerçekleştiği için toplumsaldır. Sosyal yaşamın birliktelikleri karş1l1kl111k üzerine kurduğu düşünüldügünde, farklı zaman ve mekânlar boyutunda bütün sosyal birlikteliklerde bir armağan ilişkisi olduğu söylenebilir. Bu alanın sınırları, içerdiği özellikler değişse bile önemi, varlığını her koşulda sürdürmesindedir. Bu bağlamda modern toplumda ortaya çıkan hediyeleşme biçimini geleneksel anlamda armağan ilişkileri ve karşıllılılık, bağımlılık anlamlarında ele almak gerekmektedir. Bu haliyle armağanın dayatılan bir davranış biçimi olup olmadığına bakmak gerekir (Yeşiltuna, 2007, 225). Karşı1ık bazen diğerine karş1 hissedilen bir duygunun ifadesi de olabilir. Toplumsal yaşamda her sunulanın bir karşılığının olmas1 gerektiği düşüncesine göre bu karşı1ık her zaman maddi olmayabilir. Geri dönüşünün, hizmet, duygu, saygınlık gibi sosyal, kültürel anlamlar içermesi belki de, armağanın temel beklentisi olarak değerlendirilmelidir.

$\mathrm{Bu}$ çalışma ile armağanın toplumsal işlevleri ve armağanın yarattığı bağımlılık ve karşılıklılık durumunun toplumsal düzenin işleyişine katkısından hareketle kişisel ve duygusal bağlanmanın aracı olarak, sağladığı toplumsal bütünleşme ilişkisi nedeniyle, günümüzün hediyeleşme ritüellerinden olan çiçek ve çiçek göndermenin anlamları çözümlenmektedir. Armağan ve harcamanın, cömertlik, statü ve güç ile ilişkilendirildiği ilkel toplumlardaki "potlaç" törenlerinde biriktirmenin, saklamanın lanetine inanıldığı için baharda tüketilmemiş olan tüm maddeler dağıtılır, şölenlerde de tüketilmediyse yakılır, yok edilirdi. Bir tür meydan okuma ve güç gösterisine dönüşen bu törenler günümüz toplumunda çiçek göndermek gibi maddi değerinden çok manevi değere ve "anlam" a vurgu yapan bazı sembolik uygulamalara dönüşmüştür. Bu 
çalışma ile söz konusu ilişkiyi ve dönüşümü anlamak için farklı sosyo-kültürel çevreye hitap eden üç ayrı çiçekçiyle yapılan görüşmelerin verilerinden yararlanılmıştır. Böylece konuyla ilgili kuramsal yaklaşımlar ile günümüzde gündelik yaşam içerisinde devam eden bir ritüel olan çiçek göndermenin anlamları, yapılan nitel görüşmelerin verilerinden hareketle ilişkilendirilmektedir. Çalışma, bu çerçevede konuyla ilgili kuramsal yaklaşımların anlaşılmasını ve çiçekçilerle yapılan yüz yüze görüşmelerin verilerinin konuyu örneklendirmesini içermektedir. Bu nedenle çalışmada, tarihsel dönemler içerisinde armağana yüklenen toplumsal anlamlar ve bu anlam ilişkilerinin dönüşümüne odaklanılmıştır. Bu çerçevede her ne kadar estetize edildiği iddiası ortaya atılabilirse de armağanın günümüz kapitalist tüketim toplumunda değişen anlamı, uygulamaları ve toplumsal ilişkiler bağlamında değerlendirildiğinde ilkel toplumlarda olduğu gibi günümüzde de itibar kaynağı, güç ve konum ifadesinin sembolik görünümü olduğu görülmektedir. Armağanın sembolik hediyeleşmeye dönüştüğü ve bu ilişkilerin kapitalist tüketim toplumunun pazar ilişkileri çerçevesindeki değişen anlam ve uygulamaları da çalışmanın irdelediği sorunlardandır.

\title{
Toplumsal Etkileşim ve Mübadele İlişkisi
}

Her türlü etkileşime bir tür mübadele olarak bakılabileceği düşünüldüğünde; konuşma, sevgi ifadesi (karş11ısız bile olsa), her oyun bir etkileşim aynı zamanda mübadeledir. Etkileşimde insan sahip olmadığı şeyi verirken, mübadelede sadece sahip olduğu şeyi verdiği için bu iki kategori farklıymış gibi gözükmekle birlikte aslında aynıdır (Simmel, 2009, 65). Etkileşim daha geniş mübadele daha dar anlamlar içeriyor gibi gözükmekle birlikte; gündelik insan ilişkilerinde etkileşim genelde mübadele olarak değerlendirilen görünümlerle ortaya çıkar. Simmel'e göre, günlük hayatın sıradan olayları sürekli bir kâr/zarar ilişkisi çerçevesinde değerlendirilir. Bu da hayatın içeriğinin azalıp arttığı bir gel-git durumu yaratır. Mübadele türleri arasında fedakârlık durumunu en çok barındıran ise ekonomik değerlerin mübadelesidir. Simmel, armağanın yarattığ ilişki bağını varoluşsal bağlamda değerlendirir:

\begin{abstract}
"Sırf şeylerin yan yana gelmesinden sistematik bir ilişki yaratan aynı sentezleyici zihin işlemi -maddi dünyaya kendi bütünlüklü karakterini veren aynı ben- mübadele kategorisi sayesinde varoluşumuzun doğal ritmini kapıp barındırdı ̆̆ unsurları anlamlı bir ăg halinde düzenler" (Simmel, 2009, 66).
\end{abstract}

Bağış ve hediye vermenin toplumsal olarak dayanışma ve devamlılı̆g sağladığı için bir zorunluluk olduğunu ve vermenin en az almak kadar önemli bir yükümlülük olduğunu vurgulayan Mauss (1966) bildiğimiz bu günkü toplumlardan önce yalın toplumlarda karş1lıklı yükümlülük altına girenin ve değiş tokuş ya da anlaşma yapanların bireyler değil topluluklar olduğunu belirtir. Bu süreçte karşı karşıya gelen, alışverişi gerçekleştiren klanlar, kabileler ve ailelerdir. Bu süreçte önemli olan ve sosyal bağları güçlendiren ve değiş tokuş edilen şeyler sadece mallar değil, karşılıklı nezaket gösterileri, şölenler, ayinler, askeri hizmetler, kadınlar, çocuklar, eğlenceler, bayramlar ve fuarlar gibi neredeyse tüm toplumsal olguları içeren geniş bir alandır. Sonuçta bu yükümlülükler ve karşı yükümlülükler tamamen zorunlu olmalarına rağmen çoğunlukla isteğe bağlı bir biçimde ve armağanlarla yerine getirilir. $\mathrm{Bu}$ durumu düzenleyen, kendiliğinden ve rızaya dayalı gibi algılanmasını sağlayan da sosyalleşme sürecinde içselleştirilen toplumsal değerlerdir. Toplumsal moral değerler, inanışlar, söylemler, gündelik rutinler, armağan ilişkisinin yani karşılıklılık ve dayanışmanın yerleşmesini, pekişmesini sağlar. Armağanı reddetmek uğursuzluk sayıldığı için armağanı kabul etmek ve karşılığını zamanı geldiğinde vermek toplumsal bir yükümlüğe dönüşür. Yükümlülüğü belirleyen, sürekliliği sağlayan zorlayıcı güç ise adeta mistik bir yapıya işaret eder. Bu anlamda bir şey sunmak, vermek ise kendinden bir parça vermekle eşdeğerdir: 


\begin{abstract}
"Maori hukukunda verilen şeyin kendisi de ruh sahibidir ve ruhun bir parçasıdır... Birine bir şey sunmak kendinden bir şey sunmaktır. Böylece hediyeler üzerinden yapılan değiş tokuşun yapısında, birinden bir şey kabul etmek, onun tinsel özüne, ruhuna ait bir şeyi kabul etmektir. Bir şeyin kabul edilememesi tehlikeli ve ölümcül olabilir. Çünkü verilen şey ruhsuz ve etkisiz değildir" (Mauss, 2006, 223).
\end{abstract}

Bu toplumlarda, bireyin kendi huzuru için sevdiği şeylerden vazgeçebilmesi gerekmektedir. Kurban törenleri, tanrılara ya da doğaüstü güçlere sunulan adaklar gibi kendisine ait olanın bir kısmını diğerleriyle paylaşmak durumu da çoğunlukla kendi esenliği ve huzuru için bireyin kendisine ait bir mülkten eşyadan, kaynaktan vazgeçmesini gerektirir. Verilen şeyin bir geri dönüşünün olacağı düşüncesi bireye sorumluluk yükleyerek zincirleme ilişkiler sisteminin kurulmasını sağlar. Gönüllülük esasına dayanan bu eylemler özünde toplumsal ve psikolojik fayda elde etmeyi hedefler. Karşılığında sosyal itibar ve psikolojik rahatlama için ödenmesi gereken bedeller söz konusudur ve bu zorunluluklar aynı zamanda gönüllü ve rızaya dayalı eylemler olarak değerlendirilmelidir. Çünkü zorunluluğu yaratan sosyal ağlar içindeki beklentiler ve yatırımlardır. Dolayısıyla hediyeyi geri vermek, hediye almak kadar önemli bir zorunluluktur. Vermeyi reddetmek, davet etmeyi ihmal etmek, almayı reddetmek, söz konusu yalın toplumlarda savaş ilan etmektir. Reddetmek süregelen düzeni, ittifakı ve birliği bozmaya yönelik olarak algılanır. Bu toplumlarda besin, kadın, çocuk, mülk, büyü, toprak, iş, hizmet, dini görev ve mevki gibi her şeyin bir duyguyu iletme ve bir nesneyi teslimi söz konusudur. Mauss'a (2006, 224-228) göre, her şey sürekli değiş tokuş ediliyormuş gibi gelir ve gider. Hediyelerin değiş tokuş edilmesi nihai olarak büyük zenginlik yaratır. Verilen şeyin azalmak yerine artacağı düşünülür. Paylaşmak tüketmeye değil, söz konusu olan şeyin çoğalmasına neden olmaktadır. Zira her nesnenin bir tini olduğu varsayıldığından ve nesnenin özüyle bireyin ruhunun bir arada düşünülmesi kişilerin, eşyaların ve ruhların birbirine karışıp kaynaştığı bir döngüyü ifade eder. $\mathrm{Bu}$ inanış, eşyaların dağıtılması, kullanılmasıyle bağlantılı olarak gelişen ve ruhun da bir anlamda dolaşımda olduğu bir ilişkiler sistemine vurgu yapar. Bu üretim ilişkileri her armağan alışverişinde yeniden üretilmekte ve toplumsal yeniden üretim bu sayede gerçekleşmektedir (Akay, 1999, 160).

Değiş tokuş edilen eşyalar, değiş tokuşu yapan kişilerden hiçbir zaman tam anlamıyla bağımsız değildirler. Mauss'a (2006, 264-285) göre, bu şeylerin yarattığı birlik ve ortaklık göreceli olarak ayrılmazdır. Gerçekte toplumsal yaşamın bu sembolik durumları bölümlere ayrılan bu toplumlardaki grupların sürekli olarak iç içe geçiş şeklini ve her şeyi birbirlerine borçlu hissetme biçimini dolaylı olarak ifade etmektedir. Bu gruplar sürekli tekrar eden bir mübadele ilişkisinden dolayı iletişim, etkileşim halinde olmak zorundadırlar. Sosyal bağ koparmak bu durumda mümkün değildir. Yalın toplumlarda hediyeler geri verilme güvencesiyle dolaşıma girerler ve bütün bu karşı yükümlülüklerin gerçekleşmesi için bir zaman aralığ gereklidir. Kişinin bir hediyeyi geri çevirmesi durumu, iadede bulunmaktan ya da iade yapılmadığı sürece ezik kalmaktan korkmak anlamlarına gelmektedir. Sunulanı kabul etmemek, sosyolojik olarak iktidar, erk sahibi olamamak anlamlarına gelmektedir. Çünkü hediyeyi geri çevirmek saygısızlık olarak algılandığ 1 gibi, geri çeviren için de karşılıkta bulunamamak, misliyle geri verecek zenginlikte ve güçte olmamak, dolayısıyla zayıf olmak, yenilmek anlamlarını içerdiği için toplumsal olarak aşağılanmayı, dışlanmayı göze almayı gerektirir. Böylece bu zorunlu karşılıklılık zincirleme olarak devam eden sosyal ilişkiler ve yükümlülüklerle toplumsal bağların devamlılığını sağlayan bir işleve sahiptir.

\title{
Değişen Toplumla Birlikte Değişen Armağan İlişkisi: Potlaçtan Kitlesel Hediyeye
}

$\mathrm{Bu}$ çalışmada armağan ve hediye kavramları aynı anlamda kullanılmakla birlikte; armağan daha 
çok bir ekonomik sisteme ve mübadeleye işaret ederken; hediye kavramı daha çok kişisel alanda gerçekleşen ve kişiler arası etkileşimi ifade eden dolayısıyla maddi değerden çok sembolik değeri olan ve duygusal yatırım ve beklentiler içeren süreçlere denk gelmektedir. Potlaç, yalın toplumlardaki önemli bir güç gösterisinin gerçekleştiği törenlere denir. Malların tüketilmesi, yakılması, yok edilmesiyle gerçekleşen bu sosyal şölen söz konusu dönemlerde grubun önde gelenlerinin, rakiplerinin gözü önünde, onlara meydan okuyarak en güçlünün kendisi olduğunu gösterme çabası olarak tanımlanabilir. Bu anlamıyla törene ev sahipliği yapanın malından vererek, onu yok ederek, bir anlamda eşyanın, şeylerin esiri olmadığını kanıtlaması söz konusudur. Bu durum gücü elinde bulunduranın kendi mülkünün üzerindeki yetkisiyle ve onu yok ederken rakiplerine gözdağı vermesi anlamlarını da barındıran bir güç gösterisi olarak tanımlanabilir. Potlaç; bir şefin kendisiyle eşit ya da rakip durumdaki kişileri, değerli eşyalarının parçalanıp yağmalanmasına tanık olmaları için davet ettiği toplumsal şölenler olarak tanımlandığında; burada cömertlik, sahip olunan eşyanın elde kalmaması (sahip olunan şeylerin elde kalması uğursuzluk getirir; dolayısıyla bu toplumlarda biriktirme söz konusu değildir) için düzenlenen ritüellerde, aynı zamanda bir güç gösterisi, meydan okuma, cömertliğiyle övünme ve harcama, yok etme yoluyla rakiplerine gözdağı verme, onları alt etme durumudur.

Armağan ile potlaç ilişkisi değerlendirildiğinde; armağan ilişkisinde armağanı kabul etmek ve ister karşılığında bir armağan vermek ya da armağanı verene karşı sadakat ve hizmet sunarak ödeşmek gereklidir (Burke, 2008, 50). Potlaçta ise vermeden çok, kaybetme ilkesi hâkimdir. Bir güç gösterisi olarak sahip olduklarından, onları yok ederek vazgeçmek söz konusudur. Burada eşyanın esiri olmayı, metaların bireye hükmetmesini ve mülkün eşit olmayan sosyal ilişkiler kurulmasına neden olmasını önlemek, belki de bir tür eşitlik, aynılık sağlamak hedeflenmektedir. $\mathrm{Bu}$ durumu, gerçek zenginliğin kaynağının mal biriktirmek değil, harcamak, tüketmek ve sembolik güç ilişkilerinden geçtiğinin sosyal ifadeleri, döneminin sosyal adalet sistemini anlatan ritüeller olarak yorumlamak mümkündür. Söz konusu toplumsal uygulamalarda kaybetme ve harcama, zenginliğin kaynağı olarak sunulmaktadır. Kaybedenin kapitalist dünyadaki konumu, mutsuzluğu yerine armağan ekonomisinin hâkim olduğu toplumlarda kaybetmeyenin, vermeyenin, harcamayanın mutsuzluğu söz konusudur. Harcama yapmak, meydan okumak ve kendi zenginliğini karşıdakine tanıtmanın yoludur. Bu anlamda harcama değişimin ilk ilkesidir. Değişim, bireyler arası iletişimi başlatan ilke ve insani bir eylemdir ve harcayanın yaşam kalitesini artırır. Mauss'a göre potlaçta geçerli olan ilke alınandan fazlasının iade edilmesidir. Akay $(1999,13)$ ise, potlacın saklama ilkesinin tam karşıtı olarak tanımlandığını vurgular. Böylece Weber'in Protestan Ahlakı'nın kapitalist zihniyetinin kurucu ilkesinin karşısına başka bir ahlak modeli olarak çıkmaktadır.

Potlacın geçerli olduğu toplumlarda birey toplumsal statüsünün garantisi olarak harcamaya yönelir. Armağan ekonomisinde kendi statüsünü korumak, harcama yapmak ve zenginlikten kaybetmek, tükenmek ve tüketmeye dayanmaktadır. Sınırsız tüketim modeli kapitalist birikim modelinin karşıtıdır. Kapitalizm her ne kadar süregelen bir tüketim biçimine dayanmakla birlikte bu ekonomide esas olan biriktirmektir. Harcamak, tüketmek bireyin kendisi için yaptığ bir eylemdir ve başkaları için, malından vermek, dağıtmak gibi uygulamalar ve vermeye yüklenen anlam potlaç ekonomisindekinden oldukça farklıdır. İlk toplumlarda güç ve iktidar harcama yapmak, oyunlar oynamak, kumarda kaybetmek, törenlerde harcamalar yapmak, artan ürünü tüketmek, yakmak, yok etmekten geçmektedir. Potlacın yani gösterişçi tüketimin, yok etmenin, elindekini karşısındakini ezerek dağıtmanın "bir prestij kaynă̆ı" olduğunu vurgulayan Harris $(1995,106)$ salt bir gösteriş merakı ya da ölçüsüz ve çılgın bir savurganlıktan çok; potlacı kendi bağlamında değerlendirilmesi gereken bir ekonomik ve kültürel tören olarak tanımlanması gerektiğini ifade etmektedir.

Armağan vermenin psikolojik temelleriyle ilgili düşüncelere bakıldığında Godbout'nun 
Mauss'dan aktardığına göre, verme dürtüsü insanlık tarihi açısından değerlendirildiğinde alma arzusu kadar önemlidir. Yani bir şeyi, duyguyu verme, aktarma, karş1l1k verme, merhamet ve cömertlik, alma, sahip olma, elinde tutma ve iştah ya da bencillik kadar esas olan duygulardandır (Godbout, 2003, 43). Akay'a $(1999,14)$ göre, armağan ekonomisi hediye vermek, altın, para takmak, ölümden sonra sofra kurmak gibi pratiklerle tek tanrılı dinlerde de devam etmektedir. Kapitalist toplumda ise zenginlikler artık duvarların ardında, bankalarda veya mal ve mülklerle saklanmakta, biriktirilmektedir. Zenginliğin saklamaktan geçtiği, bankalar ve duvarlar arkasına hapsedildiği kapitalist toplumlarda armağanın görünümleri de değişmiştir. Nurit ve Darr, (2009, 305) armağan ve armağana ilişkin tutumların tüketim teorileri, tüketim toplumu ve kültürel teori ilişkisini bu alandaki çalışmaların merkezinde olduğunu vurgulayarak "kitlesel hediye" kavramını kullanıyorlar. Pazar ve tüketim ilişkileri içinde özellikle bazı alanlardaki zincir mağazalar ve süpermarketlerde ürünün pazarlama, satış ve sunuş biçiminin "hediyeler" adı altında sunularak tüketim ve pazarlama yöntemlerine dönüştüğünü vurguluyorlar. Buradaki temel sorun armağanın muğlâklaşan tanımıdır. Örneğin satılan bir maldan "bir alana bir bedava" ya da ikincisinin hediye olduğu durumlar ya da bir tane alana diğerinin büyük oranda indirimli olduğu kampanyalarda hangisinin hediye olduğuna kim karar verecektir? Bu anlamda çoğunlukla günümüzde armağan ile tüketim malzemesinin temelde karşıtmış gibi görünmelerine rağmen birlikte yer aldıklarını söylemektedirler.

Akay (1999, 37), armağan ekonomisinden günümüze gelindiğinde, ilk toplumlardaki vererek zenginleşme inancının, yani ne kadar çok dağıtılırsa, harcama yapılırsa mülkünün o denli katlanarak artacağına olan inanç nedeniyle mümkün olduğunca çok vermenin geçerli olduğu bir durumu hatırlatır. İlk toplumlarda elindekinden, sahip olduğundan fazlasını vermek, harcamak kuralı günümüzdeki uygulamasıyla bankalardan kredi almak ile eşdeğerdir. Armağanı vermek kredi yani saygınlık kazanacaktır Bir anlamda günümüz ekonomisinde birey, elinde olmayan ama gelecekte sahip olacağı parasını, zenginliğini de kullanabilmektedir. Bu kredinin bir takım teminatlar sonucu verildiği düşünülürse, kredi sahibinin söz konusu toplumda saygınlık sahibi olduğu söylenebilir. Batının tarihi de bu anlamda incelendiğinde farklı değildir; Akay, Batı tarihinde de onurlu olmak, zengin olmak gibi sosyal anlamların yolunun harcamadan geçtiğini vurgulamaktadır. Ayrıca maddi karş11ık beklememek, armağanın karşılıksız olduğu anlamına gelmez. Vicdanı rahatlatan, güven duygusu veren ve armağan karşılığında bir biçimde korunacağını, kötülüklerden arınacağını düşünen birey için aldığı hediyenin bedelini daima bir şekilde ödeyeceği düşünülebilir. Öyle ki, sevgi ve güven duygusunu içeren özel ilişkilerde bile bu tip manevi beklentilerin armağanla ilişkilendirildiği söylenebilir.

Yani armağan, artı değer üretmekten, biriktirmekten çok, elde olanın dağıtılması, verilmesi fikrine dayanır. Akay'ın aktarımıyla; Battaile harcama ekonomisinde fayda dışı bir durumdan bahseder. Üretimden çok tüketmenin söz konusu olduğu durumlarda, onurla, ödevle, zevk almayla ilişkilendirilen harcama düşüncesi üretkenliğe dayanmaz. Akay $(1999,72)$ armağanın başka bir anlamının ise Derrida ile felsefi bağlama taşındığını söyler. Bu bağlamda, Derrida'ya göre; vermek - armağan vermek; karşı armağan almak ile zaman vermek - zamanını vermek arasında yakın bir ilişki vardır. Venkatesan (2011) ise, Derridacı bir bakışla armağan ilişkisini değerlendirdiği çalışmasında; armağanın bazen karşılıksız olduğunu Mauss'un armağana karşılıklılık düşüncesine karşın, aslında armağan düşüncesinin geri dönüş beklentisini içermediğini savunur. O'na göre; hiyerarşik olarak üst konumdaki birine sunulan bir armağan bazen sadece alıcı tarafindan bir saygınlık ve saygı ifadesi olarak algılanır. Armağan ne geçmişte yaşanmış bir şeyin karşıllığı ne de gelecekte bir beklenti içermemelidir. Armağanı kabul eden de veren de zorunlu bir karş1lıklılık düşüncesine sahip değildir Ancak bu durumda bile bir yatırımın olduğu, kişisel güven ve tatminin söz konusu olduğu göz ardı edilmemelidir. Diğer yandan bunlar da bir tür beklenti, yatırım olarak değerlendirilebilir. Zaman ve armağan ilişkisi düşünüldüğünde, 
zaman, armağan gibi verilen bir şeydir. Bu anlamda somut olarak sahip olunamayan, maddi karşıllı̆̆ olmayan ama kendinden olan bir şeyi, karşıdakine vermek anlamında "zaman” en değerli hediyelerden biridir. Özellikle günümüz kapitalist toplumlarında zamana ekonomik değer biçilmesi ve modern insanın zamanının çok kısıtlı olması, zaman yönetiminin profesyonel bir uğraşa dönüşmesi, zamanın değerli bir hediye olarak algılanmasını gündeme getirmiștir. Karşıdakine zaman ayırarak ona değerli olduğu mesajı verilir ve böylece onun uğruna fedakârlık yapıldığı ima edilir. Bu anlamda günümüzde zaman, Simmel'in yaklaşımına referansla etkileşim biçimi olarak karşılık beklentisiyle verilen bir tür hediye olarak değerlendirilebilir. Bu hediye genellikle özel alanda, özel kişilere verilen bir hediye olarak ifade edilir.

\section{Armağan ve Özel Alan - Toplumsal Cinsiyet İlişskisi}

Armağanın potlaç bağlamında değerlendirilmesi söz konusu dönemlerde toplumsal bağlara ve sürekliliğe atıfta bulunan bir durum almasına karşın, kapitalist toplumlarda tüm toplumsal süreçlerin, duyguların bile ticari ilişkiler bağlamında değerlendirildiği düşüncesi; bu toplumlardaki özellikle özel ve yakın ilişkilerdeki hediyeleşme ile kırılmaktadır. Bir anlamda hediyeleşme kapitalist toplumlarda bireylerin duygusal olarak "nefes aldıkları", gergin durumun yumuşatıldığ bir alan olarak değerlendirilebilir. Smith $(2007,107)$ Mauss'un sanayi toplumlarına ilişkin armağan ile ilgili fazla bir şey söylememiş olmasına rağmen Noel, doğum günü, hatta bir barda içki ısmarlamak gibi durumları, yozlaştırıcı bir ticari ruhun toplumsal yaşamı henüz bütünüyle kuşatmadığının bir kanıtı olarak yorumlamak gerektiğine vurgu yapar. Bir şeyin henüz alış ve satış üzerinden ifade edilmemesinin, tüm kapitalist ilişkilerine rağmen modern toplumun bir tür şansı olduğunu söyler. Bu durum günümüz geçerli ahlâkının sadece ticari olmadığının bir kanıtıdır. Armağan ilişkisine veren ve kabul eden açısından yüklenen anlamların çözümlemesini, yaptıkları uygulamalı çalışmayla tartışan Parsons ve arkadaşlarına göre; armağanı kabul edenler açısından değerlendirildiğinde; taraflar arasında yakın ilişki söz konusu ise armağanın sembolik anlamları ön planda olmaktadır. Taraflar, yakın ilişkide olan ama yeni tanışan insanlar ise armağanın temel anlamlarının önemli olduğu gözlenmektedir. Bu anlamda ilişkinin niteliğinin verilen armağanla tanımlanabileceği söylenebilir (Parsons, Ballantine, \& Kennedy, 2011). Başka bir ifadeyle armağanın hangi anlamının öne çıkacağını belirleyen de taraflar arasındaki ilişkinin düzeyidir. Armağan bir anlamda sosyal ilişkilerin düzenlendiği, tanımlandığı bir alanı içermektedir.

Armağan ve toplumsal cinsiyet dolayısıyla özel alan ilişkisi kurulmaya çalışıldığında; Bourdieu erkeklerin evlilikte simgesel iktidarı koruduklarına vurgu yapar ve evlilik stratejilerinde erkeklerin özne konumunda olduklarını, kadınların ise bu mübadele ilişkisinde nesne konumunda olduğunu vurgular. Buradan hareketle özel alanda yani cinsiyetler arasındaki ilişkide hiyerarşik bir durum söz konusu olabileceğinden armağan ilişkisinin "simgesel şiddete" (Bourdieu, \& Wacquant, 2003, 173; Silber, 2009) neden olabileceği yorumu yapılır. Armağan ilişkisini toplumsal cinsiyet ilişkileri bağlamında ev ve özellikle de oturma odasında sergilenen metalar bağlamında ele alan çalışmasında gündelik yaşam pratikleri içinde armağanın daha çok kadınla ilişkilendirildiğini vurgulayan Hurdley’e (2007) göre hediyenin kadınsılaştırılması, daha çok duyguların metalaştırılmasını da içeren toplumsal cinsiyet hiyerarşileri anlamında eşitsiz bir ilişkiye neden olmaktadır.

Armağan ilişkisi elde olmayanın verilmesi bağlamında düşünüldügünde aşkla sevgiyle ilişkilendirilmektedir (Akay, 1999, 89). Çünkü aşk ve sevgi ilişkisinde duyguların ifadesi ve alışverişi söz konusudur. Dolayısıyla bu mübadele biçiminde somut bir değer biçme söz konusu değildir. Yani duygusal bir alışveriş söz konusu olduğunda kişiler arasında arkadaşlık, sevgi duygusunun yaratılmasına çalışılır ve istenilen etkinin güçlendirilmesi hedeflenir. Bu tür armağan ilişkisinde duygusal bir yatırım ve karşılık beklentisi söz konusudur. Ancak bu durum en açık ifadeyle bir şeyin oluşturulma çalışması olduğundan henüz var olmayan bir şeyin değişimini 
ifade eder. Aslında bütün bunlar bir tür bütünleşmeyi, iç içe geçişe gönderme yapar. "Ruhlar ve hayatlar birbirine karışır, şeyler ve insanlar kendi dünyalarından çıkıp birbiriyle bütünleşirler ve bu tam anlamılla anlaşmayı ve karşılıklı değişimi ifade etmektedir" (Mauss, 2006, 239). Bauman $(1998,111)$ bireyler için tüm hayat alanını kapsamasa bile kişisel bağlamın ve yakın sıcak, duygusal ilişkiler kurmanın vazgeçilmez olduğunu vurgulamaktadır. O'na göre; yoğun bir nüfus ve çeşitlilik barındıran yaşadığımız dünyada bireyler sonu gelmez bir anlam ve birlik arayışı içindedirler. Bu arayışı "özkimlik" arayışı olarak tanımlar ve bunun kamusal alandaki kişisel olmayan mübadele ilişskilerinin hiç birinde karşılanamadığını söyler. Çünkü özel alanda ve etkileşimde karşılıklı geçişi söz konusu olan durum, anlamlardır: "mademki nesnelerle insanlar arasında ilişki kurulabiliyor; o halde mananın mübadelelerle alakası var. Çünkü mana iletilebilen bir şey, iletişime sokulabilen bir şey, insanlar arasında ve objeler arasında" (Akay, 1999, 22). Armağan verme, alma aşamalarında, insanların kendi benzersizliklerini ortaya koyma ve biçimlendirilmesini sağlayan birincil, samimi sosyal ilişkiler kurulur. Hediye vererek karş1mızdakinin özel ve benzersiz ve değerli olduğunu vurgularız. Dolayısıyla özel alanda hediyeleşmek bireyin vazgeçilmez olduğunu vurguladığı için, kendisini önemli ve varlığını anlamlı bulduğu ritüellerdendir. Dolayısıyla yabancılaşmayı azaltıcı, güven ve doyum sağlamaya hizmet eden bir görünümü söz konusudur (Godbout, 2003, 44). Armağanın duygusal yatırım içermesi ve toplumsal cinsiyet ilişkileri çerçevesinde işleyişine bakıldığında, kadının armağanı kabul eden taraf olarak tanımlandığı söylenebilir. Özellikle günümüzdeki hediyeleşme ilișkisinde kişisel alan içerisinde kadının daha fazla armağan almakla tanımlanması nedeniyle, kadınlar özel alanda armağanın merkezinde yer alırlar. Bu anlamda kadın sadece hediye alıp vermekle kalmaz, bazı aile sistemlerinde kadının kendisi bizzat hediye olarak görülür (Yeşiltuna, 2007, 233). Başka bir açıdan bakıldığında; grup içi evliliğin yasak olduğu topluluklarda ilişkilerle ilgili olarak bütün insan toplumlarında ensest yasağıyla ilgili bir uygulama olmasının toplumsal örgütlenme için oldukça önemli bir anlamı vardır. Söz konusu toplumlarda ensest grupları kabilenin birliğinde önemli işleve sahiptirler. Örneğin bireylerin başkalarıyla ilişkileri bu gruplardaki akrabalık durumlarına göre organize edilir. Bu gruplar dini törenlerde ya da ekonomik değişim durumlarında birlikler olarak hareket ederler (Benedict, 1998, 53). Tüm toplumsal süreçler bu çerçevede düzenlenirler. Değişim, etkileşim anlamında değerlendirildiğinde ise; Iş1k'a göre, evrensel ilke olması nedeniyle ensest, kadın mübadelesini gündeme getirdiğinden kültürün başlangıcı olarak ele alınmaktadır. Bu nedenle ensest yasağı, doğadan kültüre geçiş durumunu açıklar. Işık'ın aktardığı gibi, Mauss'a göre mübadele sadece ekonomik bir işlem değil aynı zamanda bütünüyle toplumsal bir olgudur ve kadın değişimi, bedenin karşılıklı mübadelesi ve bedenin üzerindeki hakların değişimi anlamlarına da gelir (Işık, 1998, 124). Ensest yasağı kadın değişimini gündeme getirdiğinde, mübadeleye maruz kalan sadece kadın ve bedeni değil, değişime konu olan iletişim kanalıyla kültürel öğeler, yaşam biçimleri ve algılamalardır. Dolayısıyla mübadele, kültürler arası etkileşimin taşıdığı anlamları da içinde barındırır.

\section{Armağan İlişskileri Çerçevesinde Hediye Olarak Çiçeğin Sunumu}

Simmel'in (2009) bireylerarası etkileşimi mübadele biçimlerinden biri olarak tanımlaması, bireyler arası etkileşimin sembolik değeri olan bazı sunumlarla gerçekleşmesini gündeme taşımaktadır. Özellikle tüketim toplumlarında metaların sembolik değerlerinin ön plana çıkması iletişim, etkileşim biçimlerinin armağan ilişkisi içinde değerlendirilebileceğini ortaya koymaktadır. Etkileşim ve ilişkiler duygu aktarımını sağlayan sembolik hediyeleşmeler üzerinden işler. $\mathrm{Bu}$ bağlamda hediye olarak çiçek ve çiçekçiliğin anlamı tartış1ırken, armağan kavramının yüklendiği anlamlar ve bu konudaki kuramsal tartışmalarla birlikte, konunun yapısı gereği yapılan yüz yüze görüşmelerle teorik bilgilerin desteklenmesi uygun görülmüştür. Çiçek verme ve hediye olarak çiçek alma günümüz toplumunda yaşayan ve sosyal işlevi olan bir durumdur. Bu nedenle çiçek verme ve almanın geçerli anlamlarını, bunun en canlı tanığı olan çiçekçilerle 
konuşarak, tartışarak desteklemenin konuyu anlama açısından önemli olacağ düşünülmüştür. Armağan kelimesinin çağrıştırdığı karş1lıklılı̆̆ın günümüzde çiçek gönderme durumunda da geçerli olduğu yapılan görüşmelerle de pekişti. Böylece hem bir meslek olarak çiçekçilik yapanların, çiçekçiliğin değișen toplumsal yapı ve yaşanan çeşitli sosyal olayların (ekonomik krizler, afetler, bayramlar, özel günler gibi) etkilerini nasıl yaşadıklarını anlatmaları, hem de günümüz açısından çiçeğin ne zaman, hangi mesajlarla, hangi biçimlerde, kimlere hediye olarak gönderildiğinin anlaşılmasının çalışmaya renk katacağı düşüncesiyle, konu bu görüşmeler çerçevesinde biçimlendi.

Hediye olarak çiçek gönderme ve çiçekçiliğin kültürel boyutu düşünüldüğünde, hediye ya da armağan kelimesinin antropolojik olarak farklı kültürlerdeki anlamlarına bakmak gereklidir. $\mathrm{Bu}$ bakışla armağanın sosyolojik işlevi göz önüne alındığında sosyal bilimciler tarafından "yalın”, ya da "yaban" olarak adlandırılan toplumlarda armağanın, toplumsal yapı içerisinde ilişkiler ağının devamlılı̆̆ını sağlayan ve toplumu bir arada tutan, dinamizmi sağlayan bir kavram olarak ele aldıkları daha önce tartışıldı. Günümüz toplumlarında armağanın görünümlerine bakıldığında ise; kapitalist toplumlarda bu durumun yok olmaya yüz tuttuğunu savunan görüşlerin yanında, armağanın ve özel alanda hediyeleşmenin bu toplumsal işlevini yitirmediğini, sadece dönüştüğünü ve sağladığı sosyal işlev nedeniyle çağdaş insana bir tür nefes alma, kendini iyi hissetme fırsatı verdiğini savunan görüşlere de rastlanmaktadır. Ahmet İnsel, Marcel Mauss'un yaban toplumlarda yani pazar ekonomisi ilişkisinin ve meta düzeninin izine rastlanmadığı dönemlerde, toplumsal ilişkinin armağan temelinde şekillendiğini söylediğini aktarırken (İnsel, 2003), günümüz kapitalist toplumlarına doğru yorumlarını devam ettiren düşünceye göre; günümüz meta dünyasında, her şeyin belirlenmiş, herkes tarafından bilinen bir fiyatının olduğu ve söz konusu karşıllğıı ödenerek o şeye sahip olunduğunun kabul edildiğini vurgular. Bir bakış açısına göre, tüketim toplumlarında her şeyin ve durumun maddi bedelinin net bir şekilde belirlenmiş olması, nesneye yüklenen anlamın ve gizemin yok olmasına, nesneler ve ilişkilerin metalaşmasına yol açar:

\section{"Bu sistem içinde insanlar da metalaşır. Illişkilere de bir değer biçilir. Her şey piyasa ekonomisinin bir parçasl olur. Oysa Pazar ekonomisinin öncesinde yüz yüze ve sürekliliği olan ilişkilerin toplumsal varoluşunu armağan ilişkisi düzenlerdi" (İnsel, 2003, 11).}

Armağan ya da hediye, içinde bulunduğu kültür ortamı içinde bir döngüyü ifade eder. Bu ilişki düzeninde armağan vermek yeterli değildir. Karşılıklı armağan vermek zorunluluğu ilişkinin sürekliliğini, kalıcılığını sağlar. Sosyal ilişkiyi düzenleyen, yorumlayan, anlamlandıran ve hatta hiyerarşik olarak sınıflandıran anlamları da ima eder. Armağan sadece alıp - verme ilişkisi değildir. Aynı zamanda güç, yarışma, cömertlik, diğerkâmlık, ötekine üstün çıkma, onur ve saygınlık arayışının çatışma ve uzlaşmanın bir ifadesidir. Armağan gönüllülük ve zorunluluğun, "toplumsal beraberlik" ve "kişisel stratejinin" birlikte var olmasını sağlayan, kimi zaman sosyal konumu ifade eden, kimi zaman verenin gücüne atıfta bulunan ve bazen de karşıdakini ezen bir süreçtir. Verilen hediyenin değeri, veren kişinin konumu tarafindan da belirlenir. Bu ilişki sistemi içinde armağan, bağlayan, sınırlayan, sosyal olarak ezen, iltifat eden anlamlar içerir. Modern toplumlarda tüketim bir disiplin aracına dönüşmüştür ama aynı zamanda statü ve saygınlık aracı olarak algılanmaktadır. Bu anlamının en belirgin olduğu mekânlar ise kentsel mekânlardır (Veblen, 2005, 69). Modern kapitalist toplumların bir göstergesi olan karmaşık sosyal ağların ve ilişkilerin yaşam alanı olan kentlerde ağıllıklı olarak sembolik tüketim aracıllğıyla ilişkilerin ve gündelik yaşamın düzenlendiği söylenebilir.

\footnotetext{
"Armağan yine de salt mekanik yaklaşımı aşar. Çözümlemeye bireysel çıkarları, beklentileri katar, ancak bunların meta değişim sistemine gerek
} 
olmadan düşünülmesini sağlar. Bu anlamda armağan bizi birbirimize mecbur kılan, bunun yarattlğı dayanışma arzusu ve zorunluluğu toplumsal ilişki ăğ içine gömülmüş bir özgürlük anlaylşı içinde düşünmeye çalışmak demektir" (İnsel, 2003, 15).

$\mathrm{Bu}$ yoruma göre, günümüzde değişen toplumsal yapıyla birlikte armağan ya da hediyeye atfedilen anlamın değiştiği düşünülse de, aslında bunun yanlış bir değerlendirme olduğu, görüntü değiştirerek devam ettiği söylenebilir. Böyle bakıldığında armağan kavramı ilk toplumlarda olduğu kadar açık ve net bir şekilde işlevini sürdürmüyormuş gibi görünse de, içinde bulunduğumuz salt çıkara dayalı olduğu iddia edilen kapitalist toplumlarda da, görünmez bir şekilde bireysel ilişkiler içinde, kaynaştırıcı, bağlayıcı, anlamlandırıcı işlevini sürdürmeye devam etmektedir. Belki de bireylerin, samimiyeti yok ettiği düşünülen bir sistem içinde sığındıkları bir kale, sığınak olmaya devam etmektedir. Bu toplumsal yapı içinde armağan ilişkisi; kısmen zorunlu kısmen gönüllü olarak oluşan bu gönüllülük ve zorunluluğun ikilemi içinde yatan duygusal yaratıcılık alanının sürekli olarak açık kaldığı bir varoluş anlamı olmaya devam etmektedir. $\mathrm{Bu}$ çerçevede armağan sosyo-psikolojik olan bir bağlamda salt ekonomik çıkarlara veya iktidar ilişkilerine indirgenemeyen bir sistemi betimlemektedir. Böylece armağan ilişkisi yaratmış olduğu varoluşsal düzlem ile kişiler arası toplumsal ilişkileri kuran, besleyen ve yeniden kurmak amacıyla karşılığını almanın güvencesini hukuki ve resmi bir zorunluluktan çok, gelenek, güven ve onur duygusunun oluşturduğu yazılı olmayan bir kurallar bütününün belirlediği durumu ifade etmektedir. Bu özellikleriyle armağan "liberal küreselleşmeyi ve dünyanın metalaşmasını dizginleyecek" başka bir toplumsal oluşumun var olabileceğinin (İnsel, 2003, 18) kanıtı gibidir. Günümüzde daha çok kişisel duygularla ilintili olarak duygu aktarımının en tarafsız ve maddi çıkardan ve pazar ilişkilerinden arınmış sembolü olan çiçek sunma bu anlamda önemli bir işleve sahip gibidir:
"Çiçeğin hediye olarak yeri başkadır. Manevi değeri var. Sevgiyi ifade ediyor. Tanışmak, kendini ifade etmek aracı olarak kullanılabilecek en iyi yol. Bir erkek hiç tanımadı̆̆ ya da yeni tanıştığ bir kadına nasıl bir hediye verebilir? Çiçek işte tüm bu sorunları çözüyor. Havayı yumuşatı- yor, sicak bir ortam yaratıyor. Genellikle kadınlar çiçeği teslim ettiği- mizde çok mutlu oluyorlar ve bunu da açıkça ifade ediyorlar" (Hasbahçe Çiçekçilik Yetkilisyle Yapılan Görüşme).

Armağan bir mübadele biçimidir. Bu mübadelenin nesnesi, bir kolye, yüzük, avlanan bir hayvan, ya da çiçek olabilir. Armağan olan nesne kendi içinde tinselliği, gizli anlamları barındırmalıdır. Bu da manevi bir "mana"sı olmasından geçer. O halde mana insanlar arası ilişkilerin kurulmasında yükümlülükler ve ödevler sistemi içinde manevi bağı oluşturan bir güçtür. Değişimi yapılan şeylerin bir manası vardır. Mana ise, bireysel bir mülk değildir ancak bir tanımlama da değildir. Ama aynı zamanda bir kişiye, bir objeye de ait olan bir anlamdır (Akay, 1999, 37). Bu bakış açısıyla hediye olarak çiçeğe baktığımızda günümüzde armağanın bu işlevini devam ettiren ve bu ruhu içinde barındıran bir hediye olarak çiçeği düşünebiliriz. Çünkü çiçek bir mana, bir anlam içinde karşıdakine takdim edilir. Hem bir hediyedir, hem bazı beklentileri ifade eder, çıkar ilişkisinin dışarıda bırakıldığını düşündürdüğü için masumdur. İlk bakışta sadece hediye olarak verildiği imasını içinde barındırır. Sadece duyguları ifade etmek için bir araç olarak karşımıza çıkar. Bu yönüyle ilk algılamada çıkar amacı gütmeyen bir süreç izlenimini verir:

"Çiçek en güzel hediyedir. Özellikle bir bayanla tanışmak için ya da kız istemeye falan giderken verilebilecek en masum ve anlaml hediyedir. Örneğin bir şirket yöneticisine nasıl bir hediye gönderebilirsin ki? Illk 
karşılaşma ya da tanışmada çiçek derdini anlatmak için uygun bir seçenek. Örneğin atamalarda ya da kurumsal bir ilişkide altın ya da maddi bir şey göndermek uygun düşmez. Çiçek bir kültürdür. Iyi dileklerin, sevginin, verilmek istenen mesajın en uygun yolu ve kırmadan yanlış anlamalara neden olmadan çiçek vermekten geçer. Çiçek sevgiyi ifade eder. Çiçek masumdur ve kabul edilir. Örneğin bir kadına viski götürsen kabul etmez ama çiçek kabul edilir”. (Sabuncakis Çiçekçilik, Şişli Şubesinde, şube yetkilisiyle yapılan görüşme. Yetkili 35 yıldır çiçekçilik yaptığını, Sabuncakis'in bu alanda bilinen ve uluslararası çalışan bir kurum olduğunu, müşteri profilinin üst gelir grubu mensupları kişiler ya da şirketler olduğunu söyledi. Bu tür müşterilerin çiçek göndermeyi tercih ettiğini anlattı. Uzun yıllar aynı müşterilerle çalıştıklarını vurguladı. Artık müşterileriyle güven ortamının oluştuğunu, bazı müşterilerin sadece çiçeği göndermek istedikleri adresi bildirip, çiçeği ve mesajı kendilerinin seçimine bıraktığını anlatarak çiçek gönderme ile sosyal sınıf arasındaki ilişkiyi dile getirdi).

Çiçek göndermenin armağanın masum yüzüne işaret ettiği yorumlarının yanında hiçbir armağanın masum olamayacağını iddia eden düşüncelere de rastlanmaktadır. Mesela, Godbout'ya $(2003,28)$ göre armağan bağlayıcı da olabiliyor. Bazı dillerde armağanı ifade eden kelime aynı zamanda zehir anlamına da geliyor. Verilen armağanı kabul edip, etmemek, bazı sorumluluklara işaret eder. Yani armağanı alıp teşekkür ederseniz, bu durum tekrar bağlanmayı kabul etmiş olmak anlamına da gelebilir ve armağanın böylece sembolik bir gücü de oluşmuş olur. Yani zehir anlamında kullanıldığında armağanın istenmeyen bir durum yaratabileceği ima edilir. Bu anlamda hediyenin kendisi ve değeriyle ilgili bir sorun olmasa bile sunulan taraf için bağlayıc1dır. Bu nedenle bazı armağanlar beğenilmediği için ya da değerinden şüphe edildiği için değil de bu bağlayıcıllğından, yaratacağı eziklik duygusundan kaçmak belki de içereceği sorumluluktan kaçmak için reddedilebilir. Armağan anlam olarak içinde bir bağ taşır ve alan için bu bağ tehlike anlamında algılanabilir. Bu durumda armağanın kabul edilmesi günümüzdeki anlamları içinde söz konusu ilişkinin niteliği düşünülerek gerçekleşir. Armağanı kabul etmek, istenmeyen bir ilişkiyi onaylamak olacağı için verilen ya reddeder ya da armağan olarak kabul edilmez. Bu bağlamda armağan daha çok kişisel ilişkilerin bir simgesi, harekete geçiricisi, seçilmiş, arzulanan, bilinçli ilişkilerin, belirleyicisi, pekiştiricisidir. Bu nedenle her şeyden önce armağanın karşılık verilmesi gereken bir olgu olduğu, yükümlülükler dayattığı varsayılır (Akay, 1999, 29).

"Bir erkek bir kadına çiçek gönderiyor ısrarla, biz hizmet üretiyoruz, yani çiçeği mesajlyla birlikte son alıcıya teslim ediyoruz. Bazen kadın almak istemiyor. Geri çeviriyor. Biz sadece aracı olduğumuzu, bu çiçeklerin parasının ödendiğini söylüyoruz. Ama kadın almak istemezse durumu müşteriye bildiriyoruz. Zaman zaman israrla götürmeye devam etmemizi isteyebiliyorlar. Bazı durumlarda kz babasıyla birlikte bize gelip; Çiçeği kimin gönderdiğini soruyorlar. Bazen polisle geliyorlar. Biz genelde söylemiyoruz. Zaten çoğunu da tanımıyoruz, para toptan ödenip fatura alınmıs oluyor. Ama çok zorda kalırsak kimin gönderdiğini söylüyoruz" (Hasbahçe Çiçekçilik, Göztepe Şubesi yetkilisiyle Yapılan Görüşme).

Hediye vermek anlamında çiçek göndermek her ne kadar sembolik olması ve duygu ifadesi anlamlarında ele alınsa da sunan açısından da ekonomik durumdan tamamen bağımsız olmadığı gözlenmiştir. Yapılan görüşmeler de gösterdi ki, çiçeğin hediye olarak sunumu yaşanan sosyal ortamdan ve sınıfsal özelliklerden etkilenmektedir. Örneğin çiçekçiliğin meslek olarak son yıllarda özellikle 2000 yılından sonra her geçen gün gerileme eğilimine girdiği ifade edildi. 
Türkiye'de 2000 yılından başlayarak yaşanan ekonomik krizin insanların asgari ihtiyaçları dışındaki diğer gereksinmelerini en aza indirmeye başlamalarının etkisinin belki de kendini somut biçimde çiçek gönderme gibi zorunlu olmayan alanlarda gösterdiği vurgulandı. Bu uygulama hem bireysel anlamda hem de kurumsal anlamda etkili olmuştur. Görüşmelerden çıkan verilere göre, şirketler bütçelerini hazırlarken ilk önce lüks harcama sayılabilecek alanlardan olan çiçek göndermeye ayrılan bütçeyi kısıtlamaya başladılar. Bunda piyasanın durumu ve ekonomik sıkıntının payının büyük olduğu yine görüşmeciler tarafından ifade edildi. Çiçek bazen de temel tüketim maddesi olmadığı için lüks tüketim olarak algılanıyor. Bu etki toplumun her kesiminde kendini hissettiriyor. Görüşülen kişiler, toplumun her katmanında ve kurumunda aynı etkiyi gözlemlediklerini anlattılar. Bu örnek hediye sunumunun, çiçek göndermenin yaşanan, sosyo-ekonomik ve kültürel durum, algılayış gibi dönemin koşullarından doğrudan etkilendiğini anlatmaktadır. Ayrıca çeşitli yardım vakıflarının yaptıkları çalışmalar, propagandalar, yetkililerin açıklamalarının da çiçekçiliği, hediye olarak çiçeğin sunumunu etkilediği ifade edildi. Görüşülen yetkililer, son yıllarda vakıfların etkinliğinin artması ve bazı yönlendirmelerle -mesela Başbakanın, Belediye Başkanları’nın- halkın organizasyonlara, açılışlara, cenazelere çiçek göndermek yerine belirli vakıfların isimlerinin, banka hesap numaralarını vererek, başka bir yardım faaliyetine yönlendirmesinin de çiçeğin algılanışına etki ettiğini, boş ve yararsız bir olay durumuna indirgediğini ifade ettiler. Bu uygulamaların çiçeği duyguları ifade eden, çıkar gözetmeyen, kişiler arası iletişimi güçlendiren bir olay olmaktan çıkarıp, tasarruf tedbirlerine takılan, israf anlamına gelen bir konuma indirgediğini anlattılar.

Ekonomik zorluklardan dolayı artık mecbur kalınmadıkça çiçek gönderilmediği de anlatıldı. 1980'li ve 1990'lı yıllarda hafta başlarında iş yerlerine eşler ve patronlar tarafından "iyi çalışsmalar" gibi mesajlarla çiçek gönderildiği, bu geleneğin artık tamamen kaybolduğu anlatıldı. Aynı şekilde gazinolar ve eğlence sektöründe de eskisi kadar çiçek gönderilmediği ifade edildi. Gazinoculuk kültürünün geçerli olduğu dönemlerde Taksim'de çiçekçilik yaptığını söyleyen yetkili (Sabuncakis Çiçekçilik), eskiden yılbaşlarında çok çiçek gönderildiğini ama artık bunun neredeyse tamamen ortadan kalktığını anlattı. Aynı yıllarda hafta başlarında, dini ve milli bayramlarda çiçek gönderme alışkanlığının daha yaygın olduğunu ve bu dönemlerde özellikle saksı çiçek gönderme alışkanlığının daha yaygın olduğunu anlattı. Anlatılara göre, 1980-90'lı yıllarda çoğu zaman çiçeğin yanında bir mücevher de gönderilirmiş. Bu uygulama gazino kültürünün geçerli olduğu dönemlerde sanatçılara gönderilen çiçeklerle birlikte de devam etmiş. Günümüze yaklaştıkça bu alışkanlığın yavaş yavaş kaybolduğu, yoğun olarak sevgililer günü, anneler günü gibi medyada yer bulan, reklamı yapılan günlerde, hediyenin ve tüketimin teşvik edildiği birkaç özel gün ile sınırlı olduğu söylendi. Çiçeği sunumunun da değişen koşullar ve algılamalarla dönüştüğü ifade edildi:

\begin{abstract}
"Şimdi tavernalar var orada da çiçek gönderme yok. Herkes bardan istediği gibi çiçeği kendisi alıp yanındaki bayana veriyor. Fiyatını umursamıyorlar böyle bir durumda. Artık gazino kültüründe olduğu gibi çiçek gönderme âdeti kalmadl. Artık insanların altın gibi daha değerli hediyeler göndermeyi tercih ediyor. Bazıları da çiçek yerine artık çikolatayı tercih ediyor" (Öz-Kardelen Çiçekçik yetkilisiyle yapılan görüşme).
\end{abstract}

Aynı yetkili, büyük alışveriş merkezlerindeki marketlerde çiçek satılmasının bu işin büyüsünü bozduğunu anlattı. Buralarda sunumun zayıf olduğunu yani çiçekçi dükkânlarında yapıldığı gibi çiçeğin özenle hazırlanmadığı, eve kadar teslim edilmediği, marketten müşterinin herhangi bir şey alır gibi çiçeği eline aldığı, sıraya girip parasını ödediğini, marketlerden daha ucuza çiçek alındığını anlatarak bunun çiçek sunma kültürüne aykırı olduğunu, böylece özenin, inceliğin kaybolduğunu ifade etti. Hatta bu durumun yemek kültüründe yaşanan "fast food" laşmanın çiçekçiliğe yansıyan boyutu olarak yorumlanabileceğini söyledi. Sadece neyin hediye olarak 
gönderileceği değil, aynı zamanda nasıl sunulacağının ve yüklenen anlamların da dönemin anlam haritalarından etkilendiği bu açıklamalardan hareketle iddia edilebilir.

Yine anlatılara göre; eskiden yılbaşı, milli bayramlarda, paskalya bayramında da çiçek gönderilme alışkanlığı daha yaygın iken, dini bayramlarda saksı çiçek gönderilirmiş. Ayrıca günümüzde düğünlerde çiçek gönderme âdetinin çok azaldığı altın göndermenin arttığını söylediler. Kadınlar gününde genellikle kırmızı karanfil gönderildiği ifade edildi. Gençler arasında çiçek gönderme alışkanlığının diğer gruplara oranla daha yaygın olduğu ancak gençlerin daha çok ucuz çiçekleri tercih ettikleri, sokaktan aldıkları ve çiçeğin anlamını artıran sunumu önemsemedikleri anlatıldı. Daha çok erkeklerin sevgililerine, eşlerine çiçek aldıklarını, çiçeğin türünün maddi duruma göre değiştiği de ifade edildi. Örneğin maddi durumu iyi olanlar daha pahalı bir çiçek olan orkideyi gönderirken, diğerlerinin gül göndermeyi tercih ettiği ifade edildi. Ayrıca yapılan görüşmelerde çiçeğin alındığ 1 yerin de önemli olduğu ortaya çıtı. Buna göre sokaktan çiçek almak ile bir çiçekçi dükkânından çiçek almak farklı mesajlar taşıyor. Alınan çiçeğin, ambalajı, alındığı yerin kartı, üzerinde genellikle kapalı zarf içinde bir not, mesajlar olması gibi özellikler çiçeği alana çiçeği gönderen hakkında bazı bilgiler, gönderenin konumu, sınıfı, ilişkiyi algılayışı ve yaklaşımıyla ilgili ipuçları vermektedir. Buna göre çiçeğin bilinen bir çiçekçiden kartıyla birlikte iyi bir sunum ve paketlemeyle gönderilmesi, çiçeği kabul edene çiçeğin rastgele bir yerden alınmadığ 1 , kendisine değer verildiği, daha özenli davranıldığı mesajlarını vermektedir. Bu nedenle çiçekçiler "biz hizmet de sunuyoruz. Çiçeğe kartımızı ekliyoruz,

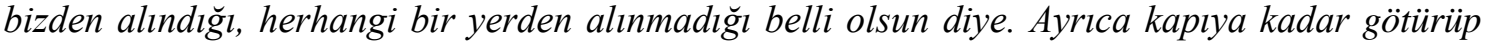
teslim ediyoruz. Bu daha şık ve çiçek göndermenin adabına uygun” diyerek aslında çiçek göndermenin sosyo-ekonomik duruma yaptığı atıfları, çiçek göndermenin bir adabı olduğu ve belirli mesajları içerdiğini anlattılar. Bunu ifade etmek için anlatılan bir örneği aktaralım:

"Ylllar önce bir erkek geldi üç vazo dolusu orkide vardı burada; yaklaşı 50 orkide eder. Çok ciddi paralar ödeyerek bu orkideleri satın aldı ve aynı kadına her gün bir tane olmak üzere bu orkideleri götürmemizi istedi. Yani yaklaşı elli gün her sabah orkideleri adrese götürdük" (Sabuncakis Çiçekçilik Şişli Şubesi yetkilisiyle yapılan görüşme).

Bazen çiçekle birlikte, yüzük, altın gibi hediyeler, doğum günlerinde de pasta veya başka bir hediye paketiyle birlikte çiçek gönderilebilmektedir. Genelde paketi çiçekçiye verip, mesajlarını kapalı bir zarfa koyup, çiçekle birlikte teslim edilmesi istenmektedir:

"Mesela bir adam iki çiçek ald zarfa da mesaj yazdı ve kendisi eve gitti. Ardından gitmemizi ve on beş dakika aralarla çiçeği karısına vermemizi istedi. Kadın ikinci kez bizi karşısında görünce sevindi. Adam da içeride bu mutluluğa şahit oluyordu" (Hasbahçe Çiçekçilik yetkilisiyle yapılan görüşme).

Bu örnek ise, çiçeğin insanlar arası duyguları yansıtan, taşıyan bir bağ olduğu, şaşırtma ve hoşluk, sıcaklık yaratmada araç olarak kullanıldığını ifade etmektedir. Çiçek bazen farklı durumlara da neden olabilmektedir:

"Sevgililer gününde bir erkek eşine 11 sevgilisine de 101 tane gülü içine de ayrı ayrı mesajlarını yazarak teslim için bize adresleri verdi. İki adres de ayn yöndeydi. Yoğun bir gün olduğu için aynı arabayla teslimata çıkılmış, teslim eden görevli adresleri karıştırıp tam tersi teslimat yapmış. Adamın sevgilisine gönderdiği 101 çiçek mesajıyla birlikte eşinin eline geçmiş. Müssteri bizi öfkeyle arayıp kızdı ve bir daha bizimle çalışmadı", (Öz-Kardelen Çiçekçilik yetkilisiyle yapılan görüşme). 
$\mathrm{Bu}$ örnek de çiçeği sunanın sunulan tarafa gönderdiği mesajın önemi, kişiye özelliği açısından çarpıcıdır. Görüşmelerde genellikle erkeklerin kadınlara, eşlerine ya da sevgililerine çiçek gönderdiği anlatıldı. Ancak tersi durumlara da rastladıklarını ifade ettiler. Örneğin bir kadının da uzun bir süre bir erkeğin iş yerine mesajlarla birlikte çiçek gönderdiği yönünde örneklere rastlandığını ancak bu tür olayların istisna olduğunu belirttiler. Çiçekçiler kurumsal ve çok özel olmayan sunumları durumlarında ise, genelde gönderenin klasik, sade ve bilinen mesajlarla çiçek göndermeyi tercih ettiğini anlattılar. Bu durumlarda çiçekçiden yardım istendiği, hazır mesaj kartları olduğunu, oradan bir mesajın seçilebildiğini, çoğunlukla eğer müşteri tanıdık ise, mesaj seçme işini çiçekçiye bıraktığını anlattılar. Ancak özel mesajların genelde gönderen tarafından önceden yazıldığı ve kapalı zarf içinde verildiği ifade edildi.

Çiçeğin gönderilme amacı ve gönderildiği kişiye göre değişiklik gösterdiği görülmektedir: çoğunlukla nişan söz, özel toplantılara "aranjman" gönderildiği, gelin çiçeğini gelinin bizzat gelip kendisinin beğendiği anlatıldı. Gelin arabası süslemesi de yine çiftlerin isteği doğrultusunda hazırlanmaktadır. Ayrıca konferans, toplantılara da çiçek gönderildiği anlatıldı. Hastanelere çiçek göndermenin artık eskisi kadar yaygın olmadığı, bunun nedeninin güvenlik sağlamak amacıyla, özellikle özel hastanelerde çiçeğin yukarı, hastanın yanına gitmesine izin verilmemesi, çiçeğin aşağıda kalması, sadece kartın hastaya ulaştırılması ve hastanın çiçeği görmemesi nedeniyle hediyenin anlamsızlaşması olarak anlatıldı. Aynı uygulamayı son dönemlerde bazı şirketlerin de yaptığı bu nedenle aynı durumun orada da söz konusu olduğu anlatıldı. Çiçek gibi tarafsız, maddi zenginlikten arınmış, duygu ifadesi gibi çağrışımları olan bir hediyenin bile çeşidinin seçiminden, sunum biçimine, kabul edilişinden, paketlenmesine ve içerdiği notlar, birlikte gönderildiği diğer hediyelere kadar birçok durum göz önüne alındığında yaşanılan kültürel, sosyal ve ekonomik koşullardan bağımsız olmadığı, sınıfsal ve hiyerarşik ilişkileri içinde barındırdığı ve tüm bu özelliklere göre organize edildiği söylenebilir. Bu anlamda çiçek sunumunun bile kapitalist ilişkilerden ve dönüşen değer yargılarından etkilendiği gözlenmektedir. Çiçekçi dükkânları yerine marketlerde ve özensiz ve kitlesel olarak satılması, yeni kuşakların hediyede sunuma özen göstermemeleri, hediye sunmanın eskiden bir inceliği, adabı olduğu gibi söylemlerden hareketle de değişen sosyal yapıdan etkilendiği söylenebilir.

Günümüzde en çok sevgililer gününde kırmızı gül ya da orkide gönderildiği ifade edildi. Orkide pahalı bir çiçek olduğu için daha çok maddi durumu iyi olanların gönderdiği vurgulandı, böylece çiçeğin aslında belirli bir maddi bedeli ve karşıllı̆̆ olduğu, bu nedenle aslında ekonomik bir gösterge olduğu da anlatılmış oldu. Anneler gününün sevgililer gününden sonra en çok çiçek gönderilen gün olduğu ifade edildi. Ayrıca bazı şirketlerin de kendi çalışanlarına çiçek gönderdiği anlatıldı. Kadınlar gününde kırmızı karanfil gönderildiği anlatılırken, genelde erkeklerin kadınlara çiçek gönderdiği vurgulandı. Ancak son y1llarda erkeğe çiçek gönderen kadın say1sında artış olduğu, bunun da kadının değişen konumuyla ilgili olduğu, kadınların eskisine oranla daha rahat davranabildikleri yönünde yorumlar yapıldı. Buna rağmen çiçek gönderen kadınların genelde isim yazmaktan kaçındıkları, belirleyici bir mesaj eklense de isim yazılmadı̆̆ının vurgulanması, kadının sosyal konumunu ifade etmesi açısından önemli bir ayrıntıdır. Erkeklerin ise genelde isimlerini yazdığı anlatıldı. Görüşülen yetkililer, çiçek gönderenlerin çoğunlukla hangi durumda, hangi çiçeği hangi mesajlarla göndereceklerini bildiklerini anlattılar. Ama bazen gelip çiçekçiye soran, kararı çiçekçiye bırakan, yardım isteyenlere de rastlandığı görüldü. Çiçeklerin anlamını sorup, hangi çiçeğin, ne zaman gönderilmesinin uygun olduğunu ve mesaj konusunda da yardım istendiği ifade edildi. Bu durumlarda bazı kalıp mesajların olduğu ve bunların kullanıldığı anlatıldı. Mesaj göndermede mesajın içeriği yakınlık ve konuma göre değişiklik göstermektedir. Hasta için "geçmiş olsun”, "acil şifalar" gibi mesajların çok kullanıldığı, doğum ise, "(bebeğin adı) aramıza hoş geldin” "seni seviyorum”, "iyi ki doğdun” gibi mesajların sık yazıldığı anlatıldı. Bu gibi geleneksel durumlarda mesajın genelde kalıp bir cümle olduğu 
ve çoğunlukla sipariş verilirken mesaj yazma işinin çiçekçiye bırakıldığı anlatıldı. Bu mesajlardan bazıları; "sıcak yuvanıza doğan güneşinizi sevgiyle kucaklyyorum”, "iyi ki varsın”, "dargın mıyız?”, "gelecek senin”, "hayatımın şansına”, "canıma”, "birbirimiz için yaratılmışız”, "şimdi ve daima”, "annem, anneciğim”, "yeni işinde başarılar" şeklinde özetlenebilir. Atamalarda ve terfilerde, "yeni görevinizde başarılar dileriz" gibi sade, bilinen mesajlarla çiçekler gönderiliyor. Gideceği yerin adresinin verilip, nasıl bir çiçek ve hangi mesajla gideceğinin çiçekçiye bırakıldığı durumlarda müşteriyle çiçekçinin birbirlerini tanıdıkları, birbirlerinin tarzlarını bildikleri ve karşılıklı güven ortamının sağlandığı gözlendi.

Bazı özel durumlarda ise çiçeği, gönderilme biçimini ve mesajı tamamen gönderen taraf belirlemektedir. Örneğin, bazı müşterilerin -genellikle erkek bir müşteri- bir adres verip, bir ay, iki ay gibi bir süre belirleyip her gün bir orkide ya da gülü aynı kadına, kapalı bir zarf içindeki mesajla götürmesini istiyor. Ödemeyi peşin yapıyor. Bu kadın genellikle bir sevgilidir. Ancak bazen erkeklerin eşlerine de aynı jesti yaptıkları gözlendi. Bazı erkekler hiç mesaj yazmadan sadece bir harf -bu gönderilecek kişinin baş harfi ya da ikisinin anlamlandırabileceği bir başka mesaj anlamına da gelebiliyor- bir simge yazarak çiçeğin belirli bir ritüelle teslim edilmesini istedikleri de anlatılar arasında dikkat çeken yöntemlerdendir. Günümüzde hediye olarak çiçeğin gönderildiği durumlar şu biçimde özetlenebilir: sevgi, aşk ifadesi olarak, doğum günü kutlaması, doğum; aileye katılan yeni bebeğin gelişini kutlamak, tebrik, genel bir kutlama, hastalara geçmiş olsun dileklerini iletmek için, özellikle anneler gününde, nikâh, düğün, açılış, cenaze, davet, organizasyon, gelin arabası süsü, gelin buketleri, söz, nişan gibi özel günler. Bu durumlar toplumsal etkileşim ve toplumsal ilişkilerin temelini oluşturan ritüellerdir. Dolayısıyla çiçek sembolik anlamlarıyla toplumsal etkileşimin kurulmasına, bağın sürdürülmesine hizmet etmektedir.

\section{Sonuç}

İnsan davranışları ve etkileşiminin belirli bir motivasyondan kaynaklandığı kabul edildiğinde, yalın yani ilk toplumlarda da günümüz toplumunda da sosyal yaşam içinde insanların yaptığ her davranışın ardında somut olarak ifade edilsin ya da edilmesin belirli bir amaç, beklenti söz konusudur. Bu durumda bireyleri harekete geçiren bir motivasyonun varlığı inkâr edilemez. Yani hediyeyi ister manevi alana ait değerler, yüce duygular umarak, ister karşıdakini mutlu ederek mutlu olmak, isterse de konumunu, saygınlığını pekiştirmek gibi beklentiler sonucu vermek, zaten hediyenin varoluş anlamları içinde gizlidir. Bu nedenle armağan ve armağana yüklenen "mana” lar günümüz "meta toplumu” içinde geçerli ve işlevseldir. Ancak günümüz toplumsal yapısının armağan ilişkilerini dönüştürdügü açıktır. Kimliklerin neredeyse tüketim ilişkileri üzerinden tanımlandığı günümüzde armağanın varlığı yadsınmasa da, ilişkiler içinde ve toplumsal iktidarın ifadesi olarak potlaçta olduğu gibi açık, meydan okuma biçiminde var olmamaktadır. Potlaçtaki toplumsal dayanışma, yarışma, onur ve saygınlık elde etme, kazanırken kaybetme, kaybederken kazanma ve sonuç olarak sonu gelmeyen biçimde birbirine bağlı kalma, birlikte var olma dinamiğinin günümüz toplumlarında daha dolaylı ve "uygar" biçimde ifade edildiği gözlenmektedir. Meydan okuma ve güç gösterileri daha incelikli, hesaplı, örtük biçimde yapılmaktadır. Uygarlaşma sürecinde yarışma ve rekabet ile bazı durumların ifade edilişi, medeni ilişkiler içinde dönüşmüş, dolaylı bir anlatımla sembolik nesneler üzerinden sunulur olmuştur. Meydan okumanın, güç gösterisinin, zenginliği ve cömertliği görünür kılmanın incelikli yolları keşfedilmiştir. Bu durumların ifadesi pazar ekonomisinin kuralları içinde gizlenmiş, başarının görünümleri değişmiştir. Dolayısıyla sahip olunan maddi güç ve metalarla doğrudan bir gövde gösterisi yapmak ayıplanır olmuştur. Armağan ve hediyeleşme daha çok özel alana ve özel ilişkilere kaymış, sembolik ve duygusal ifadelere dönüşmüştür (İnsel, 2003, 19). Godbout'a göre; her şeyin değerinin açıkça söze döküldüğü piyasa dünyasının aksine, armağan dünyası saklı olan ve söze dökülmeyenin büyük ağırlık taşıdığı bir dünyadır. Hediyeleşme anlamında 
kişiler arası duygu iletişimi ve olması istenen bir duygunun yaratılmasına hizmet eden bir durum bile tüm incelikli görünümlerinin altına bakıldığında bir karşı1lı beklentisi gizlemektedir. Karş1l1k beklemeyen bir eylem asosyal olmakla itham edilmektedir. Bu nedenle ister potlaç sisteminde olduğu gibi açıkça ve meydan okuyarak yapılsın ister günümüz toplumundaki gibi özenli sunumun incelikli ifadesi olsun tüm etkileşim çabaları duygusal, hiyerarşik ve ekonomik beklentileri içinde barındırır. Bireysel, sosyal ve psikolojik görünümleri olan bu beklentiler, sosyal konum, güven, sevilme ve ya zamanı geldiğinde bir biçimde maddi karşılık olarak ifade edilebilir. Armağan her şeyden önce ilişki kurulmasının temelini atar. Her ilişki kurma düşüncesi ise içinde karşılık umudu taşır. Godbout'a göre; zaten karşılıksızlık motivasyondan yoksundur ve tek taraflı bir durumu ifade ettiği için, artık ilişki sayılmaz. Bu nedenle armağanı bir ilişskinin yapıcı bir öğesi olarak düşünmek zorundayız. Harris'e göre Eskimolar cömert davranan ve bununla övünen armağan vericilere temkinli yaklaşmışlardır. Çünkü armağan aynı zamanda bağlanmayı da içinde barındıran bir ilişki türünü ima eder. Bir tarafiyla armağan bir sosyal bağ kurmanın belki de mükemmel bir yoludur, ancak aynı özelliğinden dolayı arzulandığı kadar da korkutucu olabilen bir bağdır.

$\mathrm{Bu}$ anlamda ilkel toplumlardan günümüze armağan, karşılıklılık gibi kavramların içeriğinin dönüştüğü iddia edilse bile bu bir tür yanılgıdan öteye gitmemektedir. Sadece biçimi ve sunumu değişmiş; fakat özü aynı kalmıştır. Akay’a göre; tükenmek, tüketmek, ölüm ve harcama elde olandan daha fazlasını vermek üzerine kurulu armağan ilişkisinde, potlaç kavramları sanayi sonrasındaki tüketim modellerinde de ilkel toplumlarda olduğu kadar geçerli olmaktadır. $\mathrm{Bu}$ durum toplumların dönüştüğü ve toplumsal bir evrim süreci anlayışının reddi anlamalarına gelebilir. Değişen toplumsal yapıyla birlikte sunumu, anlamları değişmiş olsa da hediye olarak salt duygu aktarımına hizmet ettiği iddia edilen çiçek sunumunun bile bir hiyerarşi içermesi ve örtük beklentileri olması yapılan görüşmelerle ve çiçeğe yüklenen anlamlarla da yeniden onayland1. Hediye olarak çiçek göndermenin güç, itibar ifadesi ve hiyerarşik anlamlara göre düzenlenmesi gibi uygulamalara açı olması, gönderenin ekonomik gücü ve konumuna uygun sunum, mesaj ileten bir kart, bazen de yanında değerli bir hediye ile çiçeğin sunulması ve istenen durumu yaratmayı hedeflemesi nedeniyle özü itibarıyla potlaç törenlerindekinden farklı olmadığı anlamlarını ifade etmektedir. Mülkü üzerinde söz sahibi olmanın, vermenin ve yok etmenin bir sosyal güç sembolüne dönüştüğü potlaç geleneğinden başlayarak günümüzdeki tüketim ilişkilerine kadar vermenin, bağışlamanın, hediyenin bir tür statü, güç ve iktidar ilişkisi örüntüleri içinde kurgulandığı söylenebilir. Özellikle kişisel alanda ve duygusal ifadelerde hediyeleşmenin aracı olan çiçek karşıdakini ezmeden, maddi güce vurgu yapmadan, sembolik anlamlarla ama belirli bir duygusal beklenti ve etkileme umuduyla yapilan bir jest olarak yorumlanabilmesine rağmen, çiçek göndermenin de toplumsal koşullardan ve güç ilişkilerinden beslenen bir ritüel olduğu gözlenmiştir. 


\section{KAYNAKÇA}

Akay, A. (1999). Armağan. İstanbul: Bağlam Yayınları.

Bauman, Z. (1998). Sosyolojik Düşünmek. Çev. Abdullah Yılmaz. İstanbul: Ayrıntı Yayınları.

Benedict, R. (1998). Kültür Örüntüleri. Çev. Mustafa Topal. Ankara: Öteki Yayınları.

Bourdieu, P., \& Wacquante, L. (2003). Düşünümsel Bir Antropoloji İçin Cevaplar. Çev. Nazlı Ökten. İstanbul: İletişim Yayınları.

Burke, P. (2008). Kültür Tarihi. Çev. Mete Tunçay. İstanbul: İstanbul Bilgi Üniversitesi Yayınları.

Game, A., \& Metcalfe, A. (2010). Presence of the Gift, Cultural Studies Review, 16(1), 189-211.

Godbout, J. T. (2003). Armağan Dünyası. Çev. Dilek Hattatoğlu. İstanbul: İletişim Yayınları.

Harris, M. (1995). Kültür Bilmeceleri: İnekler, Domuzlar, Savaşlar ve Cadılar. Çev. Fatih Gümüş. Ankara: İmge Kitabevi.

Hurdley, R. (2007). Objecting Relations: the Problem of the Gift. The Sociological Review, 55(1), 124-143.

Işık, E. (1998). Beden ve Toplum Kuramı. İstanbul: Bağlam Yayınları.

İnsel, A. (2003). Armağan Sorunsalının Açtı̆̆ı Ufuk. Jacques T. Godbout. Armağan Dünyası. 9-20. Çev. Dilek Hattatoğlu. İstanbul: İletişim Yayınları.

Mauss, M. (1966). The Gift Forms and Functions of Exchance Archaic Societies. Trans. Ian Cunnison. London: Cohen \& West LTD.

Mauss, M. (2006). Sosyoloji ve Antropoloji. Çev. Özcan Doğan. Ankara: Doğu Batı Yayınları.

Nurit. B. D., \& Darr, A. (2009). Commodity, Gift and Mass-Gift: on Gift-Commodity Hybrids in Advanced Mass Consumption Cultures. Economy and Society, 38 (2), 304-325.

Özkaya, K. E. (2011). Yaşatmak Uğruna Ölmek: Bir armağan İlişkisi Olarak Açlık Grevi-Türk Açlık Grevcileri Örneği. Toplum ve Bilim Dergisi, 120. 79-90. İstanbul: Birikim Yayınları.

Parsons, A., Ballantine P., \& Kennedy, A. (2011). Gift-Exchance: Benefits Sought by the Recipient. International Journal of Sociology and Social Policy, 31(7/8), 411-423.

Silber, I. (2009). Bourdieu's Gift to Gift Theory: An Unacknowledged Trajectory. Sociological Theory, 27(2), 173-190. Washington: American Sociological Association.

Simmel, G. (2009). Bireysellik ve Kültür. Çev. Tuncay Birkan, İstanbul: Metis Yayınları.

Smith, P. (2007). Kültürel Kuram. Çev. Selime Güzelsarı, \& İbrahim Gündoğdu. İstanbul: Babil Yayınları.

Veblen, T. (2005). Aylak Sinıfin Teorisi. Çev. Gültekin, Z., \& Atay, C. İstanbul: Babil Yayınları.

Venkatesan, S. (2011). The Social life of a "Free" Gift. Journal of the American Ethnological Society, 38 (1), 47-57.

Yeşiltuna, D. (2007). Modern Hediye Kültüründe Toplumsal Cinsiyet İnşası. Folklor/Edebiyat Dergisi, 13 (50), 223-235. Ankara: Omay Matbaası.

\section{Görüşmeler}

Hasbahçe Çiçekçilik, (Sahibiyle Yapılan Görüşme) Göztepe, İstanbul, Kasım 2005.

Öz-Kardelen Çiçekçilik, (Sahibiyle Yapılan Görüşme) Mecidiyeköy, İstanbul, Kasım 2005.

Sabuncakis Çiçekçilik, Şişli Şubesi, (Şube Yetkilisiyle Yapılan Görüşme) İstanbul, Kasım 2005. 